seen; the patch is an inch long and about a quarter of an inch in average width; it has not the stellate cells of the rush. The material has been protected in a depression in one of the artificial facets of the implement, and in a second position somewhat nearer the butt, there is further trace of the same material. My opinion is that these grass stems (or whatever stems they may be) were possibly wrapped round the basal end of the imple ment as a protection for the hand against the asperities of the flint. The asperities are very noticeable in the instrument referred to, as it has a sharp cutting edge at the butt, with none of the original bark of the flint left for convenience of holding. The vegetable material is undoubtedly as old as the implement, and the unabraded condition of the stone may account for its position in the facets.

125, Grosvenor Road, Highbury, N.

\section{Awned Carpels of Erodium}

Sir John Lubbock's address to the British Association, and Mr. Francis Darwin's paper in the Linnean Transactions, on the hygrometric awns of the achenes of Erodium and other plants, fail to give the honour to the right man. Their references reach some thirteen years back; but if they will look further they will find the late discoveries (including those of Hildebrand and Zimmerman in Pringsheim's Fahrbücher) forestalled as to Erodium by nearly half a century. In the Magazine of Natural History for 1836 is a modest contribution of nearly two pages from Robert Mallet of Capell Street, Dublin, describing and figuring his observations on the achenial awns of Erodium moschatum and Pelargonium peltatum. He finds that the awns of Erodium possess "most wonderful hygrometric sensibility." The five awns lie in grooves of the carpophore. $\mathrm{He}$ gives transverse views of the awns in various conditions of torsion, and of the carpophore (not as well executed as the similar ones of F. Darwin and Hildebrand). He states that aridity causes the awns to twist, and so to extricate themselves from their grooves, and at the same time downy filaments bristle forth from the awns, and the achenes detach themselves and fall to the ground. Here the awns still continue to twist and keep tumbling over, so as to recede from the parent plant. At last by twisting they become like balloons wafted about by every zephyr. But motive power has not ceased with the awn : the slighest hygrometric change produces motion either backwards or forwards in it ; and the constant tendency of this motion is to screze the seed into the ground (Mr. Mallet's italics). Such is the shape and great sensibility of the awns, that they may be readily applied to form most delicate hygrometers, for which purpose he had used them. Nearly all of these observations have been rediscovered and confirmed and published in elaborate form by the eminent investigatori of our own day.

Princeton College, November is

G. MACLOSKIE

The Song of the Lizard

WHILST quartered in St. Helena, at Ladder Hill, I was frequently disturbed by the "tweet-tweet" of a small lizard in the verandah and Melia trees which overshadowed it, which sounds for a long time I thought were produced by birds. It is, according to Melliss' description, the "Hemilactylus frenatus (Schleg.). - A small brown harmless lizard about four inches in length, which lives under stones and old timber in the warm lower part of the island. It seldom enters houses unless in pursuit of flies or scorpions, but is plentiful about the neighbourhood of Jamestown, where in the evening its loud chirp is frequently heard." This may corroborate Mr. Pascoe's remarks in his letter to NATURE (vol. xxv. p. 32).

2, Eastern Villas, Anglesey, Gosport

\section{A Double Egg}

I HAVE received a very remarkable egg, or rather, I should say, a double egg, laid by a hen belonging to Mr. Isaac Sharman, of Ranmoor, Sheffield. The egg weighed $4 \frac{3}{4} \mathrm{oz}$, and measured round its greatest circumference 8 inches, and its least 7 inches. In measuring the egg the shell was broken, and inside the outer shell there was no yoke but simply white of egg surrounding another perfect egg of the average size. This inner egg has the shell quite complete and hard. Mr. Sharman describes the bird as a cuckoo hen.

Sheffield Public Museum, December 12

\section{SIR ANTONIO BRADY}

$\mathrm{T}$ is always with a keen feeling of regret that we record the loss from the scientific ranks of men whose faces, as well as their names, were familiar to us by long association, and who were for years fellow-workers in the same geological area. Such a one was Sir Antonio Brady, F.G.S., who passed from among us on the 12 th inst. from an affection of the heart.

He was the eldest son of the late Mr. Anthony Brady, of the Royal William Victualling Yard, Plymouth, by his marriage with Marianne, daughter of Mr. Francis Perigal. Born in I 8 I he entered the Civil Service of the Navy as a junior clerk in the Victualling Yard, Deptford, more than fifty years since. After serving in various offices, having been promoted to head-quarters, he became head of the Contract Office and Registrar of Public Securities in 1854, subsequently assisting to reorganise that office. After the reorganisation of the office he was appointed first superintendent of the Purchase and Contract Department, retiring from the service in 1870 , when he received the honour of knighthood. Since his retirement from the public service, Sir Antonio has devoted his energies to the service of the public, and having taken a leading part in the preservation of Epping Forest for the people. was appointed a judge in the "Verderer's Court for the Forest of Epping." He also took great interest in the work of church extension, and was a member of the Ray, the Palreontographical and Geological Societies; he was also in the Commission of the Peace for Westminster. The deceased married, in 1837 , Maria, eldest daughter of the late Mr. George Kelner, of Ipswich, by whom he leaves a son, the Rev. Nicholas Brady, M.A., and two daughters.

But it is in his character of a geologist that we must now speak of Sir Antonio Brady. So long ago as I844 his attention was attracted to the wonderful deposits of brickearth which occupy the Valley of the Roding at Ilford, within a mile of his residence. Encouraged by Prof. Owen and other eminent palæontologists, he commenced to collect the rich series of mammalian remains which the Thames Valley brickearths yield. Owing, however, to their porous nature, the bones had lost, during their long interment, all their gelatine, and the earlier "finds," when exhumed, were so soft and friable that they crumbled beneath the touch, and it was not until fresh gelatine had been introduced that it was found possible to preserve these magnificent remains of the old inhabitants of this district. In his Catalogue of the Pleistocene Mammalia from Ilford, Essex (1874, 4to, printed for private circulation only) Sir Antonio Brady pays a just tribute of respect to the genius and ability of his first instructor in the art of preserving fossil bones, and acknowledges that he was indebted to Mr. William Davies, F.G.S., of the British Museum, for the preservation of most of the larger specimens in his collection.

Some idea may be formed of the enormous riches of this deposit when we find that an amateur, in his leisure hours, was able to amass nearly one thousand specimens of Mammalia from a single locality, comprising : Felis spelae, Canis vulpes, Ursus, sp., Elephas primigenius, E. antiquus, Rhinoceros leptorhinus, R. megarhinus, R. tichorhinus, Equus fossilis, Megaceros Hibernicus, Cervus elaphus; C. sp.; Bison priscus; Bos giganteus, Hippopotamus, sp. To this interesting series of fossil remains of the old fauna of the Thames Valley, we may add that the subsequent researches of Prof. Boyd Dawkins, F.R.S., and R. W. Cheadle, Esq., F.G.S., have added the "Musk-ox," Ovibos Moschatus, and the labours of F. C. J. Spurrell, Esq., F.G.S., the "Lemming." We have thus presented to us in this area the conjunction of the Northern and Southern forms of land-animals as marvellous as that which modern London exhibits to-day, in its assemblage of specimens of the genus Homo, from 